\title{
Exploring the Factors That Hinder the Growth and Survival of Small Businesses in Ghana (A Case Study of Small Businesses within Kumasi Metropolitan Area)
}

\author{
Anthony Kusi' ${ }^{1}$, Christian Narh Opata2, Tettey-Wayo John Narh² \\ ${ }^{1}$ Institute of Entrepreneurship and Enterprise Development, Kumasi Polytechnic, Kumasi, Ghana \\ ${ }^{2}$ Faculty of Business and Management Studies, Kumasi Polytechnic, Kumasi, Ghana \\ Email: anthonykusi61@gmail.com, chrisrui@yahoo.com, oseiwayo80@yahoo.com, \\ oseiwayo80@yahoo.com
}

Received 29 September 2015; accepted 24 November 2015; published 27 November 2015

Copyright (@ 2015 by authors and Scientific Research Publishing Inc.

This work is licensed under the Creative Commons Attribution International License (CC BY). http://creativecommons.org/licenses/by/4.0/

(c) $\underset{\mathrm{EY}}{\mathrm{B}}$ Open Access

\section{Abstract}

Micro, Small and Medium Scale Enterprises (MSMEs) contribute immensely to job creation, income generation and poverty reduction in emerging economies like that of Ghana. These positive contributions notwithstanding, most MSMEs in these economies have been performing poorly. This study therefore seeks to identify and analyze the challenges faced by MSMEs and proposed by appropriate measures that will enhance and sustain the vibrancy of MSMEs in order for them to perform their expected roles in the economic development process of Ghana. To be able to delve into the challenges of MSMEs in Ghana, a conceptual and theoretical framework is designed to guide the preparation of data collection instruments to suit the study. This involves a combination of survey and case study methods of data collection and analysis. The present study reveals that MSMEs are dominated by youth and female operators usually with low level of education. A further revelation is that majority of MSMEs lack qualified personnel; have poor access to credit and are usually self-financed. Based on the above, the study recommends the establishment of a common board to oversee the activities of support institutions for MSMEs. The study again proposes for the creation of MSMEs fund at all district, municipal and metropolitan areas to support MSMEs activities. Furthermore, the study is proposed for Bank of Ghana to create MSMEs bank to provide funds specifically for MSMEs development. Finally, effective implementation of the recommendation can lead to growth of MSME's sector in Kumasi metropolis and eventually results in creation of employment as well as poverty reduction. 
Keywords

\section{Growth, Survival, Poverty Reduction, Income Generation, Self-Financing, Unqualified Personnel}

\section{Introduction}

The role of MSMEs relative to innovation and the promotion of industrial development, job creation and market competitiveness, has been recognized by both academics and policy makers F([1] Beck et al., 2005; [2] Thurik and Wennekers, 2004; [3] Ayagari et al., 2003; Davidson and Henderson, 2002; [4] Storey, 1994).

Governments of both developed and developing economies attach great importance of MSMEs to their economies. In view of this, there is constant promulgation of government initiative specifically to assist the small business sector. For instance, the UK government policy on small business development has been focused on growing businesses ([5] Audretsch and Thurik, 2004; [6] Johnson et al., 2000). Similarly, [7] Getz and Petersen (2005) also reported that the EU member countries' small business support programmed to focus on growth and job creation. In the rapidly developing countries such as India and South Korea, the potential value of small businesses has been appreciated. In Africa, the potential role that small businesses can play in terms of poverty reduction, job creation, and fostering entrepreneurship is unprecedented.

However, most of these micro-small businesses receive little yet uncoordinated support from their governments. Nevertheless, a few competitive micro-small businesses are thriving and contributing to economic growth, employment creation and local development in combating poverty. Micro-small businesses have been identified to possess the highest potential for employment creation and can spread the benefits of industrial prosperity wider through their geographical distribution and wider adaptability to change circumstances (www.wesoedu.com).

According to Ministry of Finance and Economic Planning (2010), the main objectives of the government programme for development of small-scale industries were the creation of employment opportunities, mobilization of local resources, and mitigation of rural-urban migration and more-even distribution of industrial enterprises to different parts of the country (World Bank supported MSMEs in Ghana-Xinhua News Agency, Jan. 2006).

Most businesses in Ghana fall within the category of micro-small businesses. This category has an employment capacity of close to $70 \%$ of the Ghanaian labor force. They range from subsistence agriculture, agri-businesses, light manufacturing, art and craft, textiles and garments, tourism, financial services, construction businesses, carpentry, and others. Due to the lack of adequate attention and support, the growth of these micro-small businesses has suffered a great deal over the decades, leading to a drift in focus from entrepreneurship to a proliferation of petty trading nationwide (www.nextbillion.net).

\subsection{Definitions of Small Businesses}

Definitions of micro-small businesses vary from country to country. Usually it is based on such criteria as the number of employees, size of initial investment and turnover rate. Some previous studies, defined micro-small business as enterprises with up to 29 workers that engage in non-primary activities and sell at least half of their output. In both developing and developed countries, the vast majority of businesses are micro-small business.

For example, approximately 97\% of business in Mexico and Thailand are micro-small business ([8] Kantis, Angelli and Koenig, 2004; [9] Timmons, 2004).

In the United States, over 96\% of businesses similarly have fewer than 29 employees (US Small Business Administration and Census Bureau, 2006). Data from the Social Security and National Insurance Trust (SSNIT) indicates that, by size classifications, the Ghanaian private sector is highly skewed, with $90 \%$ of companies employing less than 20 persons. The Ministry of Trade and Industry (MOTI), in 1998 estimated that the Ghanaian micro-small businesses sector consists of approximately 80,000 registered limited liability companies and 220,000 registered partnerships.

Generally the target group in Ghana is defined as:

- Micro business: Those employing up to 5 employees with fixed assets (including reality) not exceeding the value of 100,000 dollars;

- Small business: Employ between 6 and 29 employees with fixed assets of 100,000 dollars and above;

- Medium business: Employ between 30 and 99 employees with fixed assets of up to 1 million dollars.

Micro-small businesses play an important role in the Ghanaian economy despite their significance; it is 
known that three out of five micro-small businesses fail within the first five years. One of the most significant challenges is the negative perception towards micro-small business. Potential client perceive micro-small business as lacking the ability to provide quality product and services and are unable to satisfy critical project demands ([10] Agyapong and Daniel, 2010).

A typical profile of micro-small businesses in Ghana is as follows:

- They are dominated by one person, with the owner taking all major decisions. The Entrepreneur possesses limited formal education, access to and use of new technologies, market information, and access to credit from the banking sector is severely limited;

- Management skills are weak, thus inhibiting the development of a strategic plan for sustainable growth;

- This target group experiences extreme working capital volatility;

- They lack technical know-how and their inability to acquire skills and modern technologies impede growth opportunities.

Despite the role played by micro-small business in poverty reduction, there are serious constraints limiting their growth and thus their contribution to poverty reduction. The most important constraints inhibiting the Micro-small business sector growth have always been the lack of conducive, non-transparent and complicated legal and regulatory frameworks coupled with acute bureaucracy. Although some of these constraints are also faced by large firms, their effect on micro-small businesses is phenomenal. Another constraint micro-small business face is inadequate markets access due to unstable market value chains and over reliance on saturated and localized markets. Purchasing power is low; transport infrastructure is poor, and most micro-small business has no knowledge of markets beyond their immediate locality ([11] Lorretta, M., 2014).

Productivity and product quality is low, due to a variety of reasons. These include inadequate and outdated technology, low levels of technical and vocational skills, and weak business management capabilities. Competitiveness is therefore low, especially when comparing products imported from neighboring countries and beyond. Most businesses lack access to capital that would allow them to address some of these weaknesses. It is known that most of these constraints could be eased through effective micro-small business institutional frameworks. A number of studies have indicated that the business institutional frameworks are crucial for sustainable and rapid growth of Micro-small businesses. These institutional frameworks are critical in view of the strong waves of globalization and against the background that Ghanaian's micro-small businesses function in an environment that is not conducive ([12] Raymond Mnenwa and Emmanuel Maliti, 2009).

\subsection{Statement of the Research Problem}

Small businesses remain the key entities for service provision and manufacturing in Ghana. World Bank data in 2000 estimated small businesses to account for more than 70 percent of industrial activities in Ghana (World Bank, 2000). Small businesses are major instruments for poverty reduction and promotion of economic development. They constitute a major source of local skills development and technology acquisition. They also create more jobs due to the labor intensive characteristics of their operations.

In spite of all these significant contributions, this sector continues to suffer massive neglect. One may attribute some of the reasons to their size and fragmented nature and lack of available information or low level of education, training and entrepreneurial skills among others. These notwithstanding, some developing countries like Taiwan, South Korea, India, China, have harnessed and utilized the potentials of this sector to their advantage. What is holding Ghana back? This study, therefore, tries to find out the possible ways of ameliorating or turning around the challenges confronting this sector so that their potentials could be utilized maximally for economic growth and development of Ghana (www.wesoedu.com).

\subsection{Research Objectives}

\subsubsection{General Objective}

The objective of this study is to explore the factors that hinder the growth and survival of small businesses within Kumasi Metropolitan Area.

\subsubsection{Specific Objectives}

1) To examine the various activities of small businesses in Ghana.

2) To explore the variables that hinders the growth and survival of small businesses.

3) To investigate the various factors that enhances the small businesses growth and survival. 
4) To develop sustainable measures to support small businesses development.

\subsection{Research Questions}

1) What are the challenges that hinder the effective and efficient performance of small businesses?

2) What ameliorative measures can be put in place to enhance development and operations of small businesses?

\subsection{Methodology}

The sources of data and materials for the study will be both primary and secondary. Primary data will be collected by the use of a structured questionnaire administered to the various small businesses in Kumasi Metropolitan Area, for information on the general perception of small-scale businesses operations, their challenges and constraints within the Kumasi Metropolis. Secondary data will be extracted from relevant textbooks, internet sources, newspapers, reports/articles, journals, bulletins and documents presented by corporate bodies, policy makers and government sources.

\subsection{Research Design}

The research design used is a descriptive research survey. This design used will be appropriate because the study will attempt to describe some aspect of the business population by selecting sample of micro-small businesses owners who will be asked to complete the questionnaires.

\subsection{Significance of the Study}

- To help micro-small businesses use the outcome of the research to improve upon their operations and services.

- It would also serve as a reference source for future studies on similar topics.

- To help practitioners and scholars to understand the small businesses development and survival process.

- To help to determine whether the current small businesses management style (practices and policies) are appropriate in emerging economies.

- To help identify problems faced by micro and small businesses and the types of assistance that needed to be provided to curb such hindrances.

\subsection{Scope of the Study}

The scope of the research will basically be in Kumasi Metropolitan Area. The study focuses mainly on factors that constrain the growth and survival of micro-small business within Kumasi Metropolitan Area.

\subsection{Study Limitation}

Limitations relative to time, logistics and funding limited the coverage of the study. The researcher covered only a percentage of MSME's that were spread throughout Kumasi Metropolis. The researcher also faced of some respondents failing to complete questionnaires given them and this limited the number of respondents who were involved in the study despite the researcher's efforts and approaches to explain the potential benefits of the study to them.

\subsection{Organization}

The first chapter of the study covered the introduction and the background of the study, the statement of the research problem, the research objectives, research questions, and significance of the study as well as the scope of the study, study limitations and the organization of the study.

Chapter 2 deals with the literature review that gives critical analysis of the subject and explains the concepts of Micro-small business in details.

Chapter 3 takes up the research design, research type, population type, sample method, sample size, research instrument, and administration of the instruments and method of data analysis.

Chapter 4 consists of the findings, interpretations and data analysis.

Chapter 5 has the summary of findings, conclusion and recommendations. These recommendations can be 
used in improving micro-small business practices.

References used in the research and appendixes are put at the last pages of the research report.

\section{Literature Review}

\subsection{Introduction}

This chapter reviews and elaborates on the ideas used to undertake this study by scholars and practitioners from their academic works, articles and journals written to explain the theories concerning the issues that constraints the smooth operations, growth and survival of micro-small scale business in Kumasi, Ghana.

As stated in Kanburi (2009) study on "assessing the performance of micro and small scale enterprises", there is no single, uniformly, acceptable, definition of a small businesses ([4] Storey, 1994). Businesses differ in their level of capitalization, sales and employment. Hence, definition that employ measure of size (number of employees, turnover, profitability, worth and others) when applied to one sector could lead to all businesses been classified as small, while the same size definition when applied to a different sector could lead to a different result (large businesses).

[13] Bolton Committee (1971), was the first who attempted to solve the definition problem when they implemented an "economic" and a "statistical" definition. Under their economic definition, they regarded a business as small if it meets the following three requirements:

1) If it is managed by owners or part owners in a personalized way and not through the medium of a formalized management structure;

2) If it has a relatively small share of their market;

3) If it is self-governing, in the sense of not being part of a large business.

The committee also brought about a "statistical" definition to be used in three main areas:

a) To find the size of the small business sector and its contribution to GDP, employment, experts, foreign exchange etc;

b) Comparing the extent to which the small business sector economic contribution has changed over time;

c) Applying the statistical definition in a cross-country comparison of the small businesses economic contribution.

These definitions were further corroborated by the Institute of Business and Finance Research (www.ibfr.com).

The European Commission (EC) also categorized the small business sector into three components:

1) Micro-businesses with 0 to 9 employees;

2) Small-businesses with 10 to 99 employees;

3) Medium-businesses with 100 to 499 employees.

[14] Grindle et al. (1988) also defined small businesses as those firms with less than or equal to 25 permanent members and with fixed assets (Excluding Land) worth up to U.S. \$50,000. United States Agency for International Development (1990s) and Mead (1984) [15] also said small businesses are firms with less than 50 employees and at least half the output is sold.

United Nations International Development Organization (UNIDO) definition for Developing Countries:

1) Micro-businesses with 5 workers;

2) Small-businesses with 5 - 19 workers;

3) Medium-businesses with 20 - 99 workers;

4) Large-businesses with 100 plus workers.

United Nations International Development Organization (UNIDO) definition for Developed Countries:

1) Micro-businesses with less than 29 workers;

2) Small-businesses with 30 - 99 workers;

3) Medium-businesses with 100 - 499 workers;

4) Large-businesses with 500 plus workers.

Considering the various definitions above, we can conclude that there is no special definition for small businesses (micro-small businesses). Thus, an operational definition is required.

\subsection{Definitions of Small Businesses in Ghana}

Despite the numerous definitions of small businesses, number of employees has been the most commonly used criteria for small scale business. As contained in its industrial statistics, The Ghana Statistical Service (GSS) ca- 
tegorizing businesses as follows:

1) Small-businesses with less than 10 employees;

2) Large-businesses with more than 10 employees.

An alternative criteria used in defining small businesses is the value of fixed assets and number of employees in the organization. Data from the Social Security and National Insurance Trust (SSNIT) reflects that, by size classifications, the Ghanaian private sector is highly skewed, with $90 \%$ of companies employing less than 20 persons, and small number of large-scale businesses. The Ministry of Trade and Industry (MOTI), in 1998 estimated that the Ghanaian sector consists of approximately 80,000 registered limited companies and 220,000 registered partnerships. Generally the target group in Ghana is defined as:

Micro business: Those employing up to 5 employees with fixed assets (including reality) not exceeding the value of $\$ 100,000$.

Small business: Employ between 6 and 29 employees with fixed assets of \$100,000 and above.

Medium business: Employ between 30 and 99 employees with fixed assets of up to \$1 million. (MSME Activities, Income levels and Poverty Reduction-Agyapong D, 2010) [10].

For the purpose of this study, the research will use the definition given by National Board for Small Scale Industry (NBSSI).

National Board for Small Scale Industry (NBSSI) in Ghana defines a small businesses as one with not more than 9 workers, has plant and machinery (excluding land, building and vehicle) not exceeding 10 million cedis; US \$9506, using 1994 exchange rate (Kayanula and Quartey, 2000) [16].

\subsection{Rationale for Small Businesses in Ghana}

The choice of micro-small businesses within the industrial sector for this study is based on the following proposition [16] (Kayanula and Quartey, 2000) as in John (2009) [17] and Solomon (2004):

1) Micro-small businesses mobilizes funds which otherwise would have been idle. The small businesses value the resource that might not be useful to the large business, make good use of these resources to support their businesses and the national economy as a whole.

2) Micro-small businesses have been recognized as a seed-bed for indigenous entrepreneurship. The small business sector is described as the natural home of entrepreneurship. It has the potential to provide the ideal environment for enabling entrepreneurs to optimally exercise their talents and to attain their professional goals. In all successful economies, small businesses are seen as an essential springboard for growth, job creation and social progress.

3) Micro-small businesses are labor intensive, employing more labor per unit of capital than large businesses. The recognition that micro-small businesses make a key contribution to employment creation has made them a central element in less developing country policies aimed at increasing employment. Small businesses employ a large proportion of the labor force and in many developing countries they are the largest employers. They also provide a productive outlet for expressing the entrepreneurial spirit of individuals and assist in dispersing economic activity throughout country (Nelson 1987) [18]. Small business, by virtue of their size, location and capital investment and their capacity to generate greater employment, have demonstrated their powerful propellant effect for rapid economic growth.

4) Micro-small businesses also promote indigenous technological know-how. These small businesses help to make use of the local technology to produce to meet the local market standard and even beyond. Example; local kente wavers.

5) Micro-small businesses uses mainly local resources, thus, have less foreign exchange requirements.

6) Micro-small businesses cater for the needs of the poor. Micros Small business have also been instrumental in bringing about economic transition by providing goods and services to a large number of people without requiring high-level training, large sums of capital or sophisticated technology.

7) Micro-small businesses easily adapt to customer requirements. In addition, these small businesses utilize local resources, use skills harnessed to produce a variety of products to suit the needs of the indigenous people because they now the problems they are facing.

\subsection{Characteristics of Small Businesses in Ghana}

1) Small businesses have direct access to international and local capital markets. 
2) Small businesses face the same fixed cost as large businesses in complying with regulations but have limited capacity to market products abroad.

3) Small businesses in Ghana are categorized into two; organized and unorganized businesses:

Organized-They have paid employees with registered offices.

Unorganized-They are made up of Artisans who work in open space, temporary wooden structures or at home and employ little or in some cases no salaried workers.

4) Small businesses in the rural areas are largely made up of family groups.

5) The major activities within this sector includes soap and detergents, fabrics, clothing and tailoring, textile and leather, village blacksmiths, tin smiting, bakeries, wood furniture, electronic assembly, ceramics, timber and mining, beverages food processing, agro-processing, chemical based products and mechanics ([19] Liedholm and Mead, 1987; [20] Osei, et al., 1993; World Bank, 1992) as stated by Sam (2004).

\subsection{Role of Micro-Small Businesses in Ghana}

According to Kanburi (2009) [18] Small businesses in the rural and urban have been one of the major areas of concern to many policy makers in an attempt to accelerate the role of growth in low income countries such as Ghana. These small businesses have been recognized as the engine through which the growth objectives of developing countries can be achieved (Lorretta M, 2014-MSMEs as engine for income and poverty reduction-A renewed approach to tackling Urban Poverty in South Africa).

They are potential sources of employment and income in many developing countries. It is estimated that small businesses employ 22\% of the adult population in developing countries ([21] Daniels and Ngwira, 1992; [22] Fisseha, 1992; [23] Daniels and Fisseha, 1993; [24] Fisseha and McPerson, 1991; [25] Gallagler and Robson, 1995).

The important role performed by these businesses cannot be overlooked. Micro-small businesses have some advantages over their large scale competitors:

1) They are able to adapt more easily to market conditions given their broadly skilled technology ([26] Emmanuel K. Okoye, 2008/2009); Repositioning SMEs in Onumba, Anambra State-Nigeria;

2) Due to their flexible nature, micro-small businesses are able to withstand adverse economic conditions ([10] Agyapong Daniel, 2010); MSME activities, Income levels and Poverty Reduction;

3) They are more labour intensive than large businesses and therefore, have lower capital costs associated with job creation ([27] Anheier and Seibel, 1987; [19] Liedholm and Mead, 1987; [28] Schmitz, 1995);

4) Small businesses perform useful role in ensuring income stability, growth and employment;

5) They are more likely to succeed in similar urban centers and rural areas, where they can contribute to the more even distribution of economic activity in a region and can help to slow the flow of migration to large cities ([29] Bernard Effah et al., 2014; IJSS-Small and Medium Bamboo and Rattan Enterprises in economic empowerment in Kumasi);

6) Because of their regional dispersion and their labor intensity, it is argued that small businesses production units can promote a more equitable distribution of income than large businesses ([30] Ogunsiji and Kayode, (2010); MSME Contribution of Economic Development);

7) Lastly, micro-small businesses improve the efficiency of domestic market and make productive use of scarce resources. Thus, facilitating long term economic growth. ([31] Beck, Demirgne-Kun and Marsimovic, 2009); MSMEs-Catalyst for economic growth, entrepreneur/income generation and poverty reduction.

\subsection{Policies for Promoting Small Businesses in Ghana}

The decline in the Balance of Payments in the 1980s and the overvaluation of the Ghanaian cedi led to reduce capacity utilization in the import dependent large business sector.

The SMEs sector in Ghana have been plagued with lack of political commitment to private sector development, reluctance of financial institutions to take risks; poor infrastructure; inadequate entrepreneurial skills; high taxes, bureaucratic red tape etc.

These culminated in the rising inflation and falling real wages which forced many formal sector employees into secondary self-employment in an attempt to earn a decent income.

As the economy declined, large business manufacturing employment stagnated (Kayanula and Quartey, 2000). According to Steel and Webster (1991) [32], small business and self-employment grew by $2.9 \%$ per annum (ten 
times as many jobs as large business employment) but their activities accounted for only a third of the value added.

It was in the light of the above that Government of Ghana recognized the contribution of the informal sector. It has recognized and paid due attention to the promotion and development of micro-small businesses for they are important vehicles to address the challenges of unemployment, economic growth and equity in the country. They were viewed as the mechanism through which a transition from state-led economy to a private oriented developmental strategy could be achieved. Thus the small businesses sector's role was re-defined to include the following (Kayanula and Quartey, 2000) [16]:

1) Assisting the state in reducing its involvement in direct production;

2) Absorbing labor from the state sector, given the relatively labor intensive nature of small businesses;

3) Developing indigenous entrepreneurial and managerial skills needed for sustained Industrialization.

\subsection{Constraints to Micro-Small Businesses Growth and Survival}

Despite the important and far reaching roles the SME sector play as well as their huge potential to initiate and facilitate sustainable economic growth in the country, micro-small businesses face a variety of challenges owning to the difficulty of absorbing large fixed costs, the absence of economies of scale and scope in key factors of production, and the higher unit cost of providing services to smaller businesses ([19] Schmitz, 1982; Liedholm and Mead, 1987; Steel and Webster, 1990).

A cursory peruses of the micro, small and medium sized enterprise review the underlisted set of constraints that are hindering their growth and development. A brief discussion of each is presented below.

\section{Lack of Capital}

Lack of capital seems to be the primary reason for business failure and is considered to be the greatest problem facing small and micro business owners. This was supported by Shafeek (2009) [33] where he said; from a business viewpoint without adequate financing, the business will be unable to maintain and acquire facilities, attract and retain capable staff, produce and market a product, or do any of the other things necessary to run a successful operation.

In their book, "small business management and entrepreneurship" 2006, Stokes and Wilson (2006) [34] stated among others that financial difficulties of SMEs arise, either because of an inability to raise sufficient funds to properly capitalize the business, or a mismanagement of the funds that do exist or a combination of both. They further explain that, access to external funds may be difficult to achieve for new or young, small and micro businesses with no track record, especially for owners without personal assets to offer as security. Stokes and Wilson (2006) go on to stress that many new owner managers, having received funds, misuse them; small businesses are notorious for their lack of proper financial controls and information. Access to finance remained a dominant constraint to micro-small businesses in Ghana. Micro-small businesses tend to face greater financial constraints than larger firms do.

Across the world, entrepreneurs typically start businesses primarily through their own savings because of limited access to startup capital (Mason, 1998) [35]. Credit constraints pertaining to working capital and raw materials, were cited by respondents in Parker et al., 1995 survey (between 24\% and 52\%). Aryeetey et al. (1994) [36] reported that $38 \%$ of the micro-small businesses surveyed mentioned credit as a constraint, in the case of Malawi, it accounted for 17.5\% of the total sample [21] (Daniels and Ngwira, 1993: 30-31). This stems from the fact that micro-small businesses have limited access to capital markets, locally and internationally, in part because of the perception of higher risk, informational barriers, and the higher costs of intermediation for smaller businesses. As a result, micro-small businesses often cannot obtain long-term finance in the form of debt and equity.

\section{$>$ Human Resources Management}

The competence of the SME owner/manager is the ultimate determinant of survival or failure. The root cause of either SME failure or poor performance is almost invariably a lack of management attention to strategic issues such as human resources management. Moreover, the early founder of the SME's personal competence in selecting the right business and running it will be crucial, as the firm is likely to be indistinguishable from the owner. Therefore, as the business develops, growth can be rapidly partial due to unwillingness or inability to draw others to help with the management of the agribusiness SME (Pasanen, 2006) [37].

In addition, the management of people (human resources management) is particularly important as it includes 
not only the personnel issues of dealing with employees, but also of managing people outside of the organization who are also critical to its success, such as key customers, suppliers, banks and investors (Stokes and Wilson 2006) [34].

There is an over-reliance on the single owner/manager of most small and micro business firms and reluctance to move away from this managerial tendency on the part of the SME owner/manager.

As a result, this translates into poor human resources practices where no new qualified staff is hired or authority and responsibility delegated to other employees (Nieman, 2006).

\section{$>$ Legal issue}

High start-up costs for businesses, including licensing and registration requirements, can impose excessive and unnecessary burdens on micro-small businesses. The high cost of settling legal claims and excessive delays in court proceedings adversely affect micro-small businesses operations.

In the case of Ghana, the cumbersome procedure for registering and commencing business are key issues often cited. However, Aryeetey et al. (1994) [36] found that this accounted for less than 1\% of their sample. For now, the absence of antitrust legislation favors larger businesses, whilst the lack of protection for property rights limits micro-small businesses access to foreign technologies.

\section{$>$ Information Technology}

Technological innovation has long been a chief contributor to progress in agribusiness and will continue to influence the growth and survival of the agribusiness SMEs (Baloyi, 2010) [37]. Small and micro agribusiness firms in developing countries like South Africa are poor and as such have no access to information technology. It is this lack of access to information technology that also bear a negative effect on the small and micro agribusiness firms' ability to survive and grow even in the Alice communal area (Baloyi, 2010) [38].

\section{$>$ Marketing}

According Shafeek (2009) [33] marketing is the one and only functional area that links the products or services of a business to its customers. He adds on to say, it is vitally important to ensure that this function is properly performed. To have a good chance of survival, a small or micro agribusiness firm needs to answer the basic strategic questions: "what markets are we targeting, with what products?” A common weakness in the (agribusiness) SME owner/managers lies in their failure to understand key marketing issues (Stokes and Wilson, 2006) [34].

Stokes and Wilson (2006) [34] is of the belief that product or service concepts and standards often reflect only the perceptions of the owner, which may not be mirrored in the market place. He adds on to say, minor fluctuations in markets can topple a newly established small/micro firms, particularly where it is reliant on a small number of customers.

\section{$>$ Business Plan}

According to Nieman and Nieuwenhuizen (2009) [39] a business plan is a written document that carefully explains the business, its management team, its products/services and its goals together with strategies for reaching goals. It is a living document that forms part of the formal planning done by firms, and serves as a tool for reducing the risk of venture failure, a benchmark for a firm's internal performance as well as a tool for accessing funds (Nieman and Nieuwenhuizen 2009) [39].

Small and micro firms by nature avoid formal planning, and as such do not have proper business plans. This in turn makes them not to be able to assess the firm's internal performance, fail to access funds such as loans, and also be exposed to the higher risk of venture failure. A business plan as a living document needs to be constantly updated in order for it to increase the agribusiness SMEs' chances of growing and surviving in the market.

\subsection{How to Determine Small Business Performance}

The factors that influence performance of micro-small businesses can be classified into two main areas as in the study of Solomon (2004): those that emanate from the businesses internal environment (labeled micro-level factors) and those associated with the external environment (i.e. the macro-level factors) (Kalleberg and Leicht, 1991; Keats and Bracker, 1988).

The micro-level determinants include the psychology and demographics of the owner-manager, the resources of the business, and the strategies adopted ([40] Kalleberg and Leicht, 1991; [41] Keats and Bracker, 1988), while the macro level determinants cover markets, economic, financial, technological, legal and political conditions as well as the socio-cultural context in which the business operates ([40] Kalleberg and Leicht, 1991; [41] Keats and Bracker, 1988; Wiklund, 2003). 
Researchers have examined small business performance using various theories associated with these micro and macro level factors. The population ecology theory is used to assess performance at the macro-level theory and resource-based and strategic adaptation theories have been used to examine performance at the micro level as well as owner-managers demographics and psychological make-up. (Okpara, John O. Wynn and Pamela, 2007) [42].

\section{Methodology}

Under methodology, we discuss the methods adopted in carrying out data collection. It describes the population and sample selected; method used in selecting the sample; the development and design of the instrument; method used to administer the questionnaire and interviews, and the procedure used in analyzing the data.

\subsection{Research Design}

The research design used was the descriptive research survey. This design used was appropriate because the study was attempting to describe some aspect of a population by selecting sample of micro-small businesses owners who were asked to complete the questionnaires. The design was also chosen as it was considered the most appropriate, relevant and would provide the needed data at less financial cost and in the shortest possible time. Besides, a higher degree of accuracy and reliability would be guaranteed using the design.

\subsection{Methods of Data Collection}

In order to obtain very reliable information, different but related methods were used to collect the needed data for this study. The two main data sources used are primary and secondary sources.

\section{- Primary Data}

The primary method of data collection takes into consideration the following instruments:

1) Questionnaire - This technique consists of series of questions written or verbal that respondents are approached will give room for different views and answers. The questionnaires designed for this study were carefully developed, pre-tested with a sample of respondents and debugged before they were distributed on a large scale. The rationale behind this was to help identify questions that could not be answered by respondents and screened them out.

2) Interviews - This is where the researcher has face to face conversations with the respondents in obtaining the needed data. Interviews will be conducted on questions which were not part of the questionnaire that was distributed. The personal interviews also enabled the researcher to clarify some questions which were ambiguous.

\section{- Secondary Data}

The secondary method of data sources were mainly documentary sources. These include that information obtained from various libraries visited, the web (internet) and official document.

\subsection{Target Population}

The targeted population consisted of owners of micro-small businesses in Kumasi Metropolis in vocational areas such as carpentry, hairdressing, farming, auto mechanics, art and craft, financial services, shoe makers, tailors, construction businesses and light manufacturing.

\subsection{Sample Method}

The sample method used is the snowball method to select respondents from small businesses for the research.

\subsection{Sample Size}

The sample size for the research was one hundred and twenty five (125) small business owners in different enterprises within Kumasi Metropolis.

\subsection{Research Instrument}

The method to gather adequate data was face-to-face interview and questionnaire. 


\subsection{Administration of the Instruments}

The researcher will administer the copies of the questionnaires personally to the respondents. Permission was sought from the owner-managers of the various micro-small businesses. Owners of micro-small businesses were given ample time of two (2) days to answer the items on the questionnaire.

\subsection{Method of Data Analysis}

The data analysis was done in this study using simple tables which involved the processing of the data from the questionnaire so as to make meaningful interpretation. The tables were used to give a clear view of the distribution of the responses given by respondents to each question in the questionnaire.

\section{Findings and Data Analysis}

This chapter presents and interprets the data collected and analyzed in Chapter 3, the data analysis which is focused on the constraints faced by micro-small business in Kumasi Metropolis was used as a case study.

In carrying out the research, a total of one hundred and twenty five (125) questionnaires were sent out to the respondents, and were fully answered and returned. The questionnaires were found useful and relevant in the study and they constituted $100 \%$ of the entire questionnaires sent to the respondents.

After a thorough and careful reading, doing a computerized statistical analysis of our findings, the following were revealed. It is shown in a frequency table for the reader to understand.

\subsection{Statistical Analysis and Interpretation}

Table 1 and Chart 1 above show that the answered and returned questionnaires include total of 125 respondents, of whom 44 were male while 81 were female. Source: Survey Data, 2015.

From the data gathered, we found out that women outweigh men because of aggressiveness of women, and have a lot of time for their businesses as compared to men who spend much of their time in watching football and reading newspaper. The information means that there are more women in the respondents than men, which is 35\% of men and 65\% women. Source: Survey Data 2015.

\subsubsection{Age of Respondents Analysis}

According to Chart 2 and Table 2 above, the age groups were divided into four. The respondents within 20 - 29 years of age are seven (15\%), 30 - 39 are twelve (35\%), and 40 - 49 are eight (30\%) in number, while 50 and above are three (20\%). The information suggest that most of the people investing in small businesses are middle aged who are trying to invest in business in order to become their own boss because there is high rate of unemployment and the best way to make it in life is having their own business. Source: Survey Data, 2015.

Table 3 talked about the marital status of the respondents of our research. Out of the $100 \%$ (125) respondent, 35\% (44) were married and 55\% (69) were single, and 10\% (12) were divorced. Source: Survey Data, 2015.

This analysis is being done to show the correlation between business growth or survival and marital status of entrepreneurs. We found out that those who are not married have enough time to plan and improve their business as compare to those who are married since they have to divide their time and attention for taking care of their homes and other stuffs. Source: Survey Data, 2015.

Results from Table 4 deals with the qualification of the respondents, out of the 125 (100\%) respondents 6 (5\%) was Masters Holders, 19 (15\%) were Bachelor Degree holders, 38 (30\%) were H.N.D holders, 12 (10\%) were S.H.S and $50(40 \%)$ were illiterates. It was revealed that Illiterate and S.H.S. entrepreneurs did not keep

Table 1. Gender analysis.

\begin{tabular}{ccc}
\hline Sex & Frequency & Percentage (\%) \\
Male & 44 & 35 \\
Female & 81 & 65 \\
Total & 125 & 100 \\
\hline
\end{tabular}

Source: Survey Data, 2015. 
Table 2. Age of small businesses owners.

\begin{tabular}{ccc}
\hline AGE & No. of Responses & Percentage (\%) \\
\hline $20-29$ & 19 & 15 \\
$30-39$ & 44 & 35 \\
$40-49$ & 37 & 30 \\
50 and Above & 25 & 20 \\
Total & 125 & 100 \\
\hline
\end{tabular}

Source: Survey Data, 2015.

Table 3. Marital status of respondents.

\begin{tabular}{ccc}
\hline Marital status & No. of respondents & Percentages (\%) \\
Married & 44 & 35 \\
Single & 69 & 55 \\
Divorce & 12 & 10 \\
Total & 125 & 100 \\
\hline
\end{tabular}

Source: Survey Data, 2015.

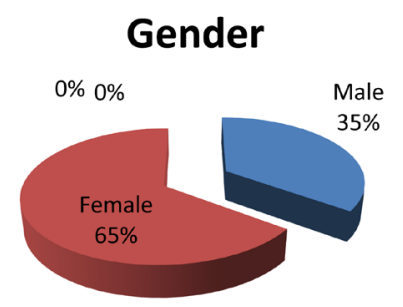

Chart 1. Gender analysis. Source: Survey Data, 2015.

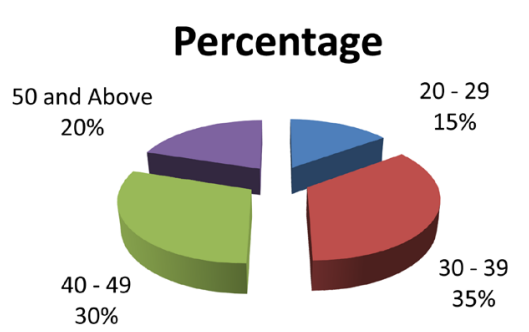

Chart 2. Age of respondents analysis. Source: Survey Data, 2015.

proper records and also could not manage their finances well and therefore their business were not sustainable. Again the Bachelor Degree holders and the Master holders also lack entrepreneurial skills to manage their business for its survival albeit the fact that they had higher educational qualifications. Source: Survey Data, 2015.

From Table 5 above, the results show that domestic demand, access to working capital, and entrepreneurial skills are the three topmost challenges to small businesses, with access to training courses being the least in terms of their ranking. Source: Survey Data, 2015.

Domestic demand (it ranked 1st with 120 responses): from the data gathered, Ghanaian proprietors indicated they had marketing constraints. It was revealed that, limited access to public contracts and subcontracts; arising from burdensome bidding procedures and lack of information, inhibits micro-small business participation in these markets as well as the perception that products from small businesses are of low quality. Source: Survey Data, 2015.

The second constraint identified in our study is the lack of access to finance (it ranked 2nd with 100 responses) by micro-small businesses in Ghana, for various reasons ranging from a lack of collateral to bias against small firms. It was indicated that, small businesses start and finance their businesses primarily through their own savings because of limited access to startup capital from financial institution. Source: Survey Data, 2015. 
Table 4. Educational level of small businesses owners.

\begin{tabular}{ccc}
\hline Level & No. of Responses & Percentages (\%) \\
Masters & 6 & 5 \\
Degree & 19 & 15 \\
H.N.D. & 38 & 30 \\
S.H.S. & 12 & 10 \\
Illiterate & 50 & 40 \\
Total & 125 & 100 \\
\hline
\end{tabular}

Source: Survey Data, 2015.

Table 5. The major challenges of businesses growth and survival.

\begin{tabular}{ccc} 
Problems & No. of Responses & 120 \\
Poor domestic demand & 100 & 1 \\
Lack of access to finance & 85 & 40 \\
Lack of entrepreneurial skills & 35 & 3 \\
Lack of appropriate Information and Technology & 30 & 20 \\
Inadequate infrastructural facilities & 6 \\
High start-up cost & 3 \\
\hline
\end{tabular}

Source: Survey Data, 2015.

Lack of entrepreneurial skills (it ranked 3rd with 85 responses) this constraint is a significant hindrance on micro-small businesses development. The scarcity of management talent, prevalent in Ghana like Kumasi Metropolis, has a magnified impact on micro-small businesses. Source: Survey Data, 2015.

The last constrain indicated by respondents is lack of training (it ranked 7th with only 20 responses). In the field of management the lack of training is a major contributor to small business failure. The respondent thought that once they raise the capital you can start any business without the necessary training. Source: Survey Data, 2015.

\subsubsection{Number of Employees}

Table 6 above shows that, majority of small businesses employ less than 5 people, constitute $45 \%$ of the total respondents, 6 - 29 persons were 35\%, 30 - 99 persons were $20 \%$, and 100 above is $0 \%$. Less than 5 employees are employed by many of small businesses due to financial problems and small nature of their business (they see it to be unnecessary to recruit many people). Source: Survey Data, 2015.

\subsubsection{Profit Projection}

The information in this frequency Table 7 is the answer to the question as to whether the business owners usually make profit out of their business as planned from the beginning. The answers provided in the table shows that $45 \%$ said they sometimes make profit as forecasted, while $20 \%$ break even as per their initial business plan and 35\% said they never make profit as they have planned from the inception of the business because of:

- Low patronage due to the misconception that

local goods are inferior;

relatively expensive;

have unreliable quality standard.

- The rapid changes in economic indicators such as interest rate and inflation rate

- Technological changes 
Table 6. Number of small business employees.

\begin{tabular}{ccc|}
\hline Person & No. of Respondants & Percentages (\%) \\
\hline Less than 5 & 56 & 45 \\
$6-29$ & 44 & 35 \\
$30-39$ & 25 & 20 \\
100 and Above & 0 & 0 \\
Total & 125 & 100 \\
\hline
\end{tabular}

Source: Survey Data, 2015.

Table 7. Does your company usually make as much profit as planned?

\begin{tabular}{ccc}
\hline Options & No. of Respondent & Percentage (\%) \\
\hline Yes & 56 & 45 \\
Break even & 25 & 20 \\
No & 44 & 35 \\
Total & 125 & 100 \\
\hline
\end{tabular}

Source: Survey Data, 2015.

- Social dynamic as relate to changes in taste and preference

- The lack of economic of scale

Source: Survey Data, 2015.

\subsubsection{Government Assistance}

Table 8 explains if the business owners get any aid from the government, 35\% said they get aid sometimes, while $65 \%$ said they never get any help from the government. The answers show that some do get aids from the government while others do not get any help at all. In my observation we realized that some small businesses do not get help from Government due to many factors such as political favor, too much lobby from larger organizations, nepotism, bribery and corruption and at times most of them are not registered. Source: Survey Data, 2015.

\subsubsection{Access to Information}

This Table 9 also explains how often the business owners get information to enhance their business profitability, $25 \%$ said they rarely get the information needed for smooth running of the business. $75 \%$ also said they do not get the information they need to influence the profit of their company or business. Source: Survey Data, 2015.

Information creates room for a new market; it also helps the business manager to know the gap in the company's supply and demand of products in their market yet $94 \%$ of small businesses do not get the needed information to influence their profit because of the cost involve in gathering data, lack of appropriate technology, inadequate experts in that field, ignorance and illiteracy on the part of business owners. Source: Survey Data, 2015.

\subsubsection{Business Turnover}

The results presented in this Table 10 shown that, turnover over "GHc 100,000-GHc 500,000" received the highest response of $45 \%$ (56), "up to GHc 100,000" turnover showed a significant respond of 30\% (38). For the same survey, the turnover category of "up to GHc 1 million" had 20\% (25) of the respond and over GHc 1 million had 5\% (6) respondent. This indicates that, majority of small businesses in Ghana and to be precise Kumasi Metropolis has a total turnover revolving around Ghc100, 000-GHc 500,000. Source: Survey Data, 2015.

\subsubsection{Bank Transactions}

From Table 11 above, 69 of the respondents representing 55\% small businesses worked with Savings and loans banks, 38 (30\%) of the respondents worked with Credit Unions, while 12 (10\%) respondents also worked with commercial banks with only $6(5 \%)$ of the respondents working with International banks. Source: Survey 
Table 8. Does your company get any help from the government?

\begin{tabular}{ccc}
\hline Options & Total Responses & Percentage (\%) \\
\hline Yes & 44 & 35 \\
No & 81 & 65 \\
Total & 125 & 100 \\
\hline
\end{tabular}

Source: Survey Data, 2015.

Table 9. Does your company get the needed information to influence the profit of the company?

\begin{tabular}{ccc}
\hline Options & Total Responses & Percentages (\%) \\
\hline Yes & 31 & 25 \\
No & 94 & 75 \\
Total & 125 & 100 \\
\hline
\end{tabular}

Source: Survey Data, 2015.

Table 10. Annual turnover of small businesses.

\begin{tabular}{ccc}
\hline Amount & Responses & Percentages (\%) \\
\hline Up to GHc 100,000 & 38 & 30 \\
GHc 100,000 to GHc 500,000 & 56 & 45 \\
Up to GHc 1 million & 25 & 20 \\
Over GHc 1 million & 6 & 5 \\
Total & 125 & 100 \\
\hline
\end{tabular}

Source: Survey Data, 2015.

Table 11. Bankers of small businesses.

\begin{tabular}{ccc}
\hline Banks & Responses & Percentages (\%) \\
\hline Commercial banks & 12 & 5 \\
International banks & 6 & 38 \\
Credit unions & 69 & 30 \\
Savings and loans (micro finance) & 125 & 55 \\
Total & 100 \\
\hline
\end{tabular}

Source: Survey Data, 2015.

Data, 2015.

\section{Summary of Findings, Conclusions and Recommendations}

A summary of the study findings, conclusions and recommendations strategically designed as the best means to explore the factors that hinder the growth and survival of micro-small businesses in Ghana and to be precise Kumasi Metropolis is presented here below.

\subsection{Summary of Findings}

The discussion centered on the most important findings regarding the impact on small business development in Ghana. From the study, the following findings were identified.

- It is not surprising to those familiar with Africa and particularly Ghana that domestic demand is a major problem (ranked 1st). Data gathered indicated that 120 out of 125 Ghanaian proprietors had marketing con- 
straints.

- Working capital was a problem (ranked 2nd or 100 responses out of 125) that many felt was particularly frustrating, regardless of where it was sought or the amount required for managing and sustaining a small business in Ghana. Some of the owners stated that it is difficult to borrow money from banks because they lack collateral. On the other hand, the loans provided by micro-finance institutions are small, with short repayment periods and high interest rates. Respondents also complained that government funds designated for small business and entrepreneurial developments are allocated to other projects. When funds are given, they are not based on any formula or merit, but rather on nepotism or favoritism. Findings further revealed that Ghana has a huge present and capable entrepreneurial spirit, but businesses cannot tap it if they are seriously handicapped by way of access to capital.

- Twenty (25\%) out of One hundred and twenty five (100\%) owners reported that lack of training and inexperience in the field of management is a major contributor to small business failure. They feel that once they raise the funds they can start any business without training or experience. Most appear impatient and do not see any need to go through the process of training and apprenticeship.

- With regard to poor infrastructure (45\% or $56 \%$ responses), services such as electricity, telecommunications, transportation, and water and sanitation play a critical role in a country's development and are directly and indirectly linked to small business success and economic growth. One respondent said Ghana's roads and bridges were "crumbling". In spite of billions of dollars spent on power generation and other infrastructure development over the years, the electricity supply in Ghana is near permanent "dumsor" i.e. regular power outages. Another respondent indicated that the majority of the populations do not have access to piped water and roads are often "pot-holed death traps". Poor infrastructure directly affects small businesses. Power failures affect the production of goods and services and inaccessible roads affect their distribution and increase transportation costs.

For example, businesses may find it problematic to operate in rural areas that are not accessible despite high demand for their products. This limits their ability to expand and opportunity to generate profit.

- The research showed that about $20 \%$ each of micro-small business owners are JHS and HND certificate holders and $40 \%$ are illiterates. It was revealed that H.N.D and S.H.S holders does not keep proper business records and therefore couldn't monitor the progress of their business which leads to mismanagement of their finances. Therefore their business couldn't sustain, again the Bachelor Degree holders and the Master holders also lack entrepreneurial skills to manage their business for its survival.

- The profitability of many businesses in their early years of their operation is a major challenge (55\%) of respondents said; they do not get profit as planned). In many instances, respondents indicated that their profits in the first two years were close to negative. Negative cash flows have also been a common attribute of start-ups, generally due to a low demand, pricing problems, high competition and, most often, soaring operating costs.

- Lack of appropriate Information and Technology is also a major cause of business failure (40) responses out of 125 or ranked 4th by respondents). In most cases this is not only due to the low priority attached to it by new entrepreneurs, but also to the lack of basic information tools and business management skills [39] (Okpara, John O. Wynn and Pamela, 2007). Most business owners end up losing track of their daily transactions and cannot account for their expenses and profits at the end of the month. Appropriate information and technology provides a small business with accurate information on which to base decisions, such as projecting sales and purchases, determining break-even points, and making other financial analyses. The prevalent lack of equipment's and proper records has led to the closure of some businesses, thereby making it a significant issue for business success.

- The information gathered from the finding suggest that most of the people investing in small businesses are middle aged (30\% - 39\% were 35\%) and young people (20\% - 29\% were 15\%) who are trying to invest in business in order to become their own boss, be respected and recognized by the society.

\subsection{Conclusions}

This exploratory study examined the reasons for small-business failure in Ghana and to be precise Kumasi Metropolis. Based on structured surveys administered to small-business owners in Ghana, several factors were identified that were responsible for small business failure in Ghana: 
- Poor domestic demand: The findings in this study indicated that poor domestic demand $(96 \%$ or 120 responses out of $100 \%$ or 125 responses) was the most responded constraint that limited the growth of micro-small businesses in Ghana and it was consistent with [43] Parker, et al., 1995; [36] Aryeetey, et al., 1994; [21] Daniels and Ngwira, 1993 as indicated in John (2009) study [17].

- Lack of working capital (ranked 2nd, 100 responses or 90\%) was next constraint to poor domestic demand identified in the study which corresponded to Parker, et al., 1995 survey (between 24\% and 52\%). Aryeetey, et al. (1994) reported that $38 \%$ of the micro-small businesses surveyed mentioned credit as a constraint, in the case of Malawi, it accounted for 17.5\% of the total sample ([21] Daniels \& Ngwira, 1993: 30-31) and Ronge, E., Ndirangu, L. and Nyangito, H. (2002) [44]. On "Review of government policies for the promotion of micro and small scale enterprises" 50\% responded "Yes".

- Regarding entrepreneurial skills, it was revealed that lack of entrepreneurial skill on the part of managers of small businesses was a hindrance to the success of these businesses. This was consistent with the findings by Daniels and Ngwira (1993) [21], which indicated that about 88\% of Malawian small businesses desired training in various skills but as at 1992 , less than $6 \%$ had actually received it.

- Lack of appropriate Information and Technology: Uncertainties surrounding new technologies restrict incentives to innovation. From the small businesses sampled, 18\% of them in Aryeetey, et al. (1994) [36] mentioned old equipment as one of the four most significant constraints to expansion (18.2\% in Parker, et al., 1995) [43].

- From the gender analysis, women were more involved in micro-small businesses than men (60\% women and $40 \%$ men) and this tended to confirm the findings of John (2009) [17] where women were more involved in micro and small agribusinesses than men from his non-financial analysis. On the rate of success of small businesses, it was revealed that female-owned businesses were just as successful as their male counterparts when size and sector were controlled as reported by Du Rietz and Henrekson (2000) [45].

- The results from the profit analysis showed that their profit efficiency was positively influenced by age, educational level, experiences and size. These findings had important policy implications in improving production efficiency among micro-small businesses in Ghana and it correspond to John (2009) [17]. Stochastic profit frontier analysis showed that their profit efficiency was positively influenced by age, educational level, farming experiences and household size.

\subsection{Recommendations}

From the foregoing analysis, findings and conclusions in the study, the following recommendations can safely be made for the stakeholders.

- Business owners should source cheap low-interest loans from friends and family, micro finance institutions and mainstream commercial banks with the intent to repay the money and also negotiate advance payments from customers.

- It is also recommended that policy makers and venture capitalists should consider providing credit to small businesses without the usual stringent collateral requirements. People with entrepreneurial intentions can also begin small savings so that such people can commence or establish their business with some initial equity capital.

- To ensure proper and accurate records keeping, appropriate technology and qualified manpower with expertise in functional areas of management should be engaged and properly compensated based on their education, experience, skills and dedication. Efforts should be made to maintain accurate records on finances, inventory, revenues, expenses, and so forth. Accounts should be kept on a daily, weekly, monthly, and annual basis using current technology.

- With respect to the challenge of entrepreneurial skills, management workshops and training seminars should be organized by key statutory agencies like the Business Advisory Centres of the National Board for Small Scale Industries (NBSSI), Private Enterprise Foundation (PEF), The Rural Enterprise Programme (REP), Non-Government Organizations (NGOs), Universities, Polytechnics and other non-profit benevolent organizations to educate small business owners about personal and financial management, basic accounting, and importance of information and communication technology, marketing strategies and recordkeeping. Business owners should network and seek mentorship from accomplished entrepreneurs in similar businesses.

- It is recommended that government on its part, should undertake to build and maintain the requisite social 
infrastructure such as roads, provision of utilities (electricity and water) for the smooth start up and operation of micro and small businesses. It is also essential for the government to create and maintain the enabling environment, stable governance arrangements and supportive government programmes and policies for the success of small business in Ghana.

\section{References}

[1] Thorsten, B., Demirguc-Kunt, A. and Levine, R. (2005) SMEs, Growth, and Poverty: Cross-Country Evidence. Journal of Economic Growth, 10, 199-229.

[2] Thurik, R. and Wennekers, S. (2004) Entrepreneurship, Small Business and Economic Growth. Journal of Small Business and Enterprise Development, 11, 140-149. http://dx.doi.org/10.1108/14626000410519173

[3] Ayyagari, M., Beck, T. and Demirgüç-Kunt, A. (2003) Small and Medium Enterprises across the Globe: A New Database. Vol. 3127, World Bank Publications. http://dx.doi.org/10.1596/1813-9450-3127

[4] Storey, D.J., Understanding the Small Business Sector (1994) University of Illinois at Urbana-Champaign’s Academy for Entrepreneurial Leadership Historical Research Reference in Entrepreneurship.

[5] Audretsch, D. and Thurik, R. (2004) A Model of the Entrepreneurial Economy. International Journal of Entrepreneurship Education, 2, 143-166.

[6] Simon, J., Boone, P., Breach, A. and Friedman, E. (2000) Corporate Governance in the Asian Financial Crisis. Journal of Financial Economics, 58, 141-186. http://dx.doi.org/10.1016/S0304-405X(00)00069-6

[7] Donald, G. and Tage, P. (2005) Growth and Profit-Oriented Entrepreneurship among Family Business Owners in the Tourism and Hospitality Industry. International Journal of Hospitality Management, 24, 219-242. http://dx.doi.org/10.1016/j.ijhm.2004.06.007

[8] Kantis, H., Angelli, P. and Koenig, V.M. (2004) Desarrollo emprendedor-America Latina y la experiencia internacional. Inter-American Development Bank, Washington DC.

[9] Timmons, J.A. (2004) New venture Creation: Entrepreneurship for the 21st Century.

[10] Daniel, A. (2015) MSME Activities. Income Levels and Poverty Reduction

[11] Muzondi, L. (2014) Women's Small-Medium and Micro Enterprises as Engines for Income-Poverty Alleviation: A Renewed Approach to Tackling Urban Poverty in South Africa. Mediterranean Journal of Social Sciences, 5, 632-638. http://dx.doi.org/10.5901/mjss.2014.v5n23p632

[12] Mnenwa, R. and Maliti, E. (2009) Assessing the Institutional Framework for Promoting the Growth of SMEs in Tanzania. The Case of Dar es Saalam.

[13] Bolton, J.E. (1971) Report of the Committee of Enquiry into Small Firms. Cmnd 4811, HMSO, London.

[14] Grindle, et al. (1988) The Dynamics of Micro and Small Scale Industries in Developing Countries. World Development Report, 26, 13.

[15] Mead, D.C. (1984) Of Contracts and Subcontracts: Small Firms in Vertical Disintegrated Production/Distribution Systems in LDCs. World Development, 12, 1095-1106. http://dx.doi.org/10.1016/0305-750X(84)90004-4

[16] Kayanula, D. and Quartey, P. (2000) The Policy Environment for Promoting Small and Medium-Sized Enterprises in Ghana and Malawi. http://www.man.ac.uk/idpm

[17] John, B.K. (2009) Assessing Performance of Micro and Small Scale Agribusinesses in Northern Ghana: Non-Financial and Stochastic Frontier Analysis. Master's Thesis, Kwame Nkrumah University of Science and Technology, Kumasi.

[18] Nelson, E.R. (1987) Promotion of Small Enterprises. In: Neck, P. and Nelson, E.R., Eds., Small Enterprises Development Policies and Programmes, ILO, Geneva, 8.

[19] Liedholm, C. and Mead, D. (1987) Small Scale Industries in Developing Countries: Empirical Evidence and Policy Implications. International Development Paper No. 9, Department of Agricultural Economics, Michigan State University, East Lansing.

[20] Osei, B., Baah-Nuakoh, A., Tutu, K.A. and Sowa, N.K. (1993) Impact of Structural Adjustment on Small-Scale Enterprises in Ghana. In: Helmsing, A.H.J. and Kolstee, T.H., Eds., Structural Adjustment, Financial Policy and Assistance Programmes in Africa, IT Publications, London, 53-70.

[21] Daniels, L. and Ngwira, A. (1993) Results of a Nation-Wide Survey on Micro, Small and Medium Enterprises in Malawi. GEMINI Technical Report No. 53, PACT Publications, New York.

[22] Fisseha, Y. (1992) Small Scale Enterprises in Lesotho: Summary of a Country-Wide Survey. Gemini Technical Report No. 14, Development Alternatives Inc., Washington DC.

[23] Daniels, L. and Fisseha, Y. (1992) Micro and Small Scale Enterprises in Botswana: Results of a Nation-Wide Survey. 
Gemini Technical Report No. 46, Development Alternatives Inc., Washington DC.

[24] Fisseha, Y. and McPherson, M.A. (1991) A Country-Wide Study of Small Scale Enterprises in Swaziland. Gemini Technical Report No. 24, Development Alternatives Inc., Washington DC.

[25] Gallagher, C. and Robson, G. (1993) The Job Creation Effects of Small and Large Firm Interaction. International Small Business Journal, 12, 23-37. http://dx.doi.org/10.1177/0266242693121002

[26] Okoye, E.K. (2008/2009) Repositioning SMEs in Onumba, Anambra State, Nigeria.

[27] Anheier, H.K. and Seibel, H.D. (1987) Small-Scale Industries and Economic Development in Ghana: Business Behavior and Strategies in Informal Sector Economies. Breitenbach, Saarbrücken.

[28] Schmitz, H. (1995) Collective Efficiency: Growth Path for Small-Scale Industry. Journal of Development Studies, 34, 529-566. http://dx.doi.org/10.1080/00220389508422377

[29] Effah, B., Boampong, E., Asibey, O., Pongo, N.A. and Nkrumah, A. (2014) Small and Medium Bamboo and Rattan Enterprises in Economic Empowerment in Kumasi: Perspectives of Producers. Journal of Social Economics, 1, 11-21.

[30] Ogunsiji, A.S. and Kayode, L.W. (2010) MSME Contribution of Economic Development.

[31] Beck, D.-K. and Marsimovic (2009) MSMEs Catalyst for Economic Growth, Entrepreneur/Income Generation and Poverty Reduction.

[32] Steel, W.F. and Webster, L.M. (1991) Small Enterprises in Ghana: Responses to Adjustment. Industry Series Paper No. 33, The World Bank Industry and Energy Department, Washington DC.

[33] Sha, S. (2009) Enhancing the Strategy for Developing Small Growth Potential Firms in the Eastern Cape.

[34] Stokes, D. and Wilson, N. (2006) Small Business Management and Entrepreneurship. 5th Edition, Thomson Learning, London.

[35] Mason, R.D. (1998) Statistical Techniques in Business Economics.10th Edition, McGraw-Hill, New York.

[36] Aryeetey, E., Baah-Nuakoh, A., Duggleby, T., Hettige, H. and Steel, W.F. (1994) Supply and Demand for Finance of Small Scale Enterprises in Ghana. World Bank Discussion Paper, No. 251.

[37] Pasanen, M. (2006) SME Growth Strategies: A Comparison of Young and Long-Lived Firms. Unpublished PhD Thesis, University of Kuopio, Kuopio.

[38] Baloyi, J.K. (2010) An Analysis of Constraints Facing Smallholder Farmers in the Agribusiness Value Chain: A Case of Farmers in Limpopo Province. Unpublished Master's Thesis, University of Pretoria, Pretoria.

[39] Nieman, G. and Nieuwenhuizen, C. (2009) Entrepreneurship. A South African Perspective. 2nd Edition, Van Schaik, Pretoria.

[40] Kalleberg, A.L. and Leicht, K.T. (1991) Gender and Organisational Performance: Determinants of Small Business Survival and Success. Academy of Management Journal, 34, 136-161. http://dx.doi.org/10.2307/256305

[41] Keats, W.B. and Bracker, J.S. (1988) Towards a Theory of Small Firm Performance: A Conceptual Model. American Journal of Small Business, 12, 41-58

[42] Okpara, J.O. and Wynn, P. (2007) Determinants of Small Business Growth Constraints in a Sub-Saharan African Economy. SAM Advanced Management Journal, 72, 24-35.

[43] Parker, R., Riopelle, R. and Steel, W. (1995) Small Enterprises Adjusting to Liberalisation in Five African Countries. World Bank Discussion Paper, No. 271, African Technical Department Series, The World Bank, Washington DC.

[44] Ronge, E., Ndirangu, L. and Nyangito, H. (2002) Productive Sector Division, Kenya Institute for Public Policy Research and Analysis, KIPPRA Discussion Paper No. 20, November 2002. Journal of Business and Entrepreneurship, 9 , 47-58.

[45] Du Rietz, A. and Henrekson, M. (2000) Testing the Female Underperformance Hypothesis. Small Business Economics, 14, 1-10. http://dx.doi.org/10.1023/A:1008106215480 